\title{
Orhun Abidelerinde Sosyal Bilgiler Dersi Öğretim Programında Yer Alan Ortak Değerler*
}

\begin{abstract}
Mustafa ŞANLI ${ }^{1}$
Ahmet KÖÇ²

Geliş Tarihi: 20.05.2021

Kabul Tarihi: 11.06 .2021

Doi: $10.47503 /$ jirss. 939893

\section{Özet}

Türk kültür ve medeniyetinin yaşatılması, gelecek nesillere aktarılması için Türk kültürüne ait eserlerin değer aktarımında kullanılması önem arz etmektedir. Bu bağlamda çalışmanın amacı, Orhun Abidelerinde Sosyal Bilgiler Dersi Öğretim Programında yer alan değer örneklerinin bulunması ve bu değerlerin Sosyal Bilgiler Dersi öğretimindeki önemi açısından değerlendirilmesidir. Çalışma, nitel araştırma yöntemlerinden doküman incelemesine uygun olarak yapılmış, abideler içerik analizi yoluyla çözümlenmiştir. Çalışmada, Muharrem Ergin'in Orhun Abideleri (2019) isimli eseri esas alınmıştır. Araştırma neticesinde Sosyal Bilgiler Dersi Öğretim Programında (MEB, 2018) adalet, aile birliğine önem verme, bağımsızlık, barış, bilimsellik, çalışkanlık, dayanışma, duyarlılık, dürüstlük, estetik, eşitlik, özgürlük, saygı, sevgi, sorumluluk, tasarruf, vatanseverlik, yardımseverlik olarak yer alan 18 değerin, Orhun Abidelerinde yer aldığı belirlenmiştir. Sonuç olarak Sosyal Bilgiler Dersi öğretiminde, Orhun Abidelerinin zengin bir kaynak olarak değer aktarımı etkinliklerinde kullanılabileceği düşünülmektedir.
\end{abstract}

Anahtar Kelimeler: Orhun abideleri, Değer eğitimi, Sosyal bilgiler dersi, Değer

\footnotetext{
* Bu makale ikinci yazar danışmanlığında birinci yazar tarafından hazırlanan "Orhun Abidelerinin Sosyal Bilgiler Dersi Öğretim Programında Yer Alan Değerler Bakımından İncelenmesi" başlıklı yüksek lisans tezinden türetilmiştir.

${ }^{1}$ Yüksek Lisans, Akdeniz Üniversitesi, Eğitim Bilimleri Enstitüsü, Türkiye, sanli_0788@hotmail.com, ORCID: 0000-0003-2607-342X

2 Prof. Dr., Akdeniz Üniversitesi, Eğitim Fakültesi, Türkiye. ahmetkoc@akdeniz.edu.tr ORCİ:0000-0002-88198095
}

Atıf künyesi: Şanlı, M. ve Köç, A. (2021). Orhun abidelerinde sosyal bilgiler dersi öğretim programında yer alan ortak değerler. Journal of Innovative Research in Social Studies, 4(1), 48-68. $\underline{\text { https://doi.org/10.47503/jirss.939893 }}$ 


\section{Common Values in Orkhun Monuments and Social Studies Curriculum}

Received Date: $20.05 .2021 \quad$ Accepted Date: $11.06 .2021 \quad$ Doi: 10.47503/jirss.939893

\section{Article Info \\ Abstract}

In order to keep Turkish culture and civilization alive and to pass it on to future generations, it is important to use masterpieces of Turkish culture in value transfer. In this context, the aim of the study is to find examples of common values in Orkhun monuments andSocial Studies Curriculum and to evaluate these values in terms of their importance in teaching Social Studies.The study was conducted in accordance with the document analysis, one of the qualitative research methods, and the monuments were analyzed through content analysis.In the study, MuharremErgin's work named Orkhon monuments (2019) was examined.

As a result of the research, it was determined that 18 values (justice, family unity, independence, peace, scientificity, diligence, solidarity, sensitivity, honesty, aesthetics, equality, freedom, respect, love, responsibility, thrift, patriotism, benevolence) in the Social Studies Curriculum (MEB, 2018) are included in the Orkhon monuments.As a result, it is thought that Orhun monuments can be used as a rich resource in value transfer activities in the teaching of Social Studies.

Keywords: Orkhon monuments, Value education, Social studies lesson, Value 


\section{GİRIŞ}

Göktürkler Bumin Kağan önderliğinde 552 senesinde bağımsızlıklarını kazanmışlardır. Göktürk devleti I. Göktürk Kağanlığı (552-630) ve II. Göktürk Kağanlığ1 (682-744) olarak iki farklı devirde ele alınabilir. I. Göktürk devleti çeşitli anlaşmazlıklar ve karışıklıklar neticesinde 630 senesinde ortadan kalkmış ve ülke Çin istilasına uğramıştır. Türkler ortalama 50 yılı Çin esaretinde geçirdikten sonra 681 senesinde Kutluğ Kağan liderliğinde özgürlük savaşına girmiş ve 682'de II. Göktürk Kağanlığı kurulmuştur (Ata, 2012: 39).

Kutluğ Kağan'ın (682-691) ardından Kapgan Kağan (692-716), Bilge Kağan(716-734) ve Köl Tigin(716-731) devirleri en güçlü devirler olarak karşımıza çıkar. Göktürk Kağanlı̆̆1, etrafındaki bütün düşmanları dize getirmiş ve çevresinde barışı hâkim kılmıştır. Fakat 731'de Köl Tigin'in ölümü üzerine kardeşi Bilge Kağan tek başına kalmış, kendi vezirinin onu zehirlemesi üzerine 734 senesinde hayatını kaybetmiştir. Daha sonra devletin başına geçen kağanların devleti iyi yönetememesi üzerine 745 senesinde Uygur Devleti, II. Göktürk Kağanlığını ortadan kaldırmıştır (Ata, 2012: 47-48).

Şimdiki Moğolistan sınırlarının içinde kurulmuş I. Göktürk Kağanlığı zamanından (550-630) kalmış ve bizlere kadar gelmiş Türkçe olan bir yazıt veya belge yoktur. (...) Runik harflerinin bulunduğu, Türkçe olan en eski yazıtlar II. Göktürk zamanından kalmıştır (Tekin ve Ölmez, 2014: 19). Göktürk zamanından kalan bu eski yazıtlar Orhun Abideleri veya Orhun Yazıtları isimleriyle tanınan; Bilge Kağan, Kül Tigin ve Tonyukuk yazıtlarıdır. Çalışmanın temel kaynağını, bu üç yazıt oluşturmaktadır.

Orhun Abidelerinden Kül Tigin Abidesi, Kül Tigin'in abisi olan Göktürklerin kağanı Bilge Kağan tarafından 732 yılında kardeşi Kül Tigin adına, kardeşinin hizmetlerinden ötürü kardeşine duyduğu minneti ifade etmek maksadıyla dikilmiştir. Bu yazıtta Bilge Kağan konuşmuştur. Ergin, "Kül Tigin Abidesi, kă̆an olmasında ve devletin kuvvetlenmesinde birinci derecede rol oynamış bulunan kahraman kardeşine Bilge Kağan'ın duyduğu minnet duygularının ve kendisini sanatkarane bir vecd ve coşkunluğun içine atan müthiş teesürün ebedi ifadesidir." (Ergin, 2019: 18) şeklinde belirtmiştir. Bilge Kağan Türkler için olduğu kadar kendisi için de oldukça büyük bir anlam ve kıymet anlamına gelen kahraman kardeşi Kül Tigin'in vefatı üstüne, ağlamak, feryat etmek istemiş ancak bulunduğu kağanlık mertebesi, tüm milletinin üstündeki sorumlu olma duygusu buna karşı gelmiştir. Bu şekilde bir durumun sadece birkaç sözcükle aktarılması, Türk edebiyatının ilk yazılı eserleri adına büyük bir edebi değeri göstermektedir (Ercilasun, 2015: 132). Türk milletinin tarihinde en önemli kişilerden olan milli değerimiz Kül Tigin adına yaptırılan bu yazıtı Yollug Tigin yirmi günlük süre zarfında yazmıştır (Atsız, 2014: 101).

Abidelerden ikincisi ise, Bilge Kağan Yazıtıdır. Bilge Kağan yazıtı, Bilge Kağan'ın 734 yılındaki vefatı üzerine, oğlu Tengri Kağan tarafından 735 yılında babası adına yaptırılmıştır. $\mathrm{Bu}$ abidede de konuşan Kül Tigin kitabesindeki gibi Bilge Kağan'dır. Bilge Kağan'ın yazıtında da İstemi ve Bumin Kağan dönemlerindeki şevket dönemi, Çin'e nasıl tutsak düşüldüğü ve bu esareti nasıl kırdıkları, bu dönemde verilen mücadeleler ve Bilge Kağan'ın Türk milletine katkıları anlatılmıştır (Ercilasun, 2015: 133). Türk dili tarihinin ilk yazılı eserleri olarak kabul edilen Kül Tigin ve Bilge Kağan yazıtları genellikle 'Orhon Yazıtları' ismiyle bilinir. Sebebi de bu yazıtların bugünkü Moğolistan'da Baykal Gölü'nün güneyinde, Orhun Nehri vadisinde Koço-Çaydam Gölü yakınlarında dikilmesi ve 1889 senesinde Yadrintsev tarafından orada tespit edilmeleridir (Tekin, 2018: 10). 
Tonyukuk Kitabesini İlteriş Kağan'ın isyanına katılan ve Bilge Kağan dönemine kadar devlet yönetiminin kağandan sonraki en etkili ismi olarak kalan büyük Türk devlet adamı ve başkomutanı vezir Tonyukuk, yaşlılık zamanında kendisi diktirmiştir. Bu yazıtta Tonyukuk konuşmaktadır ve abidenin müellifi Tonyukuk'un kendisidir (Ergin, 2019: 20). Bu yazıt 720725 yıllarında diktirilmiştir. Yazıtta Türklerin bağımsızlık mücadelesi için yapılan savaşlar ve Bilge Tonyukuk'un Türk milleti için yaptıkları anlatılmaktadır. Tonyukuk Göktürk tarihinin en önemli kişilerindendir. İlteriş Kutluğ Kağan, 17 askeriyle Çin'e baş kaldırdığında, Bilge Tonyukuk da onlarla beraberdi (Atsız, 2014: 93). Ayrıca Bilge Tonyukuk ölümünden önce anılarını kaydettirmesi bakımından ilk Türk hatıra yazarı olarak kabul edilebilir. Tonyukuk yazıtı 1897'de Klementz tarafından Kül Tigin ve Bilge Kağan yazıtlarının yaklaşık 360 kilometre uzağında, Tola Irmağı'nın yukarı yatağındaki BaynTsokto bölgesinde bulunmuştur (Tekin, 2018: 10).

Rus bilgini Yadrintsev 1889'da daha sonra Kül Tigin ve Bilge Kağan yazıtları olduğu ortaya çıkan Orhun Abidelerini tespit etmiş, bundan sonra 1890'da Heikel'in liderliğini yaptığı bir Fin, 1891 senesinde de Radloff'un öncülüğünde bir ilim grubu yazıtların olduğu yere gönderilmiştir. Bu iki ilim heyeti de yazıtları ele alarak incelemiş ve fotoğraflarını temin ederek geri dönmüşlerdir. Fin ve Rus heyetlerinin getirmiş olduğu kopyalar Avrupa ilim merkezlerine dağıtılmıştır. Ayrıca hem Radloff hem de Fin heyeti, getirdikleri materyalleri büyük atlaslar halinde neşretmişlerdir. $\mathrm{Bu}$ yayınlarla beraber anıtların okunması çalışmalarına hız verilmiş; başka yazıtları da çözmüş olan Danimarkalı büyük bilgin Vilhelm Thomsen 1893'te Orhun yazısını yani anıtların dilini çözmeyi başarmıştır. Önce abidelerde fazla geçen Tengri, Türk ve Kül Tigin kelimelerini çözmüş olan Thomsen, sonrasında bütün abideleri okuyup, sonucunda da Türk milletinin sonsuz teşekkürüne mazhar olmuştur (Ergin, 2019: 21-22).

Kül Tigin ve Bilge Kağan kitabelerinde evrenin ve insanlığın meydana gelmesi bir tümce ile ifade edildikten ve Birinci Kağanlık döneminde yaşananlar anlatıldıktan sonra İkinci Kağanlı̆̆ın kurulmasından, Kül Tigin'in 731 senesinde ölümüne kadar olan askeri ve siyasi olaylar anlatılmaktadır. Tonyukuk kendi kitabesinde ise çoğunlukla İlteriş Kağan ile Bilge Kağan'ın amcası Kapgan Kağan'ın üstün gayretlerini ve kendisinin devlete yaptığı hizmetleri anlatır (Tekin, 2018: 14).

Ergin (Ergin, 2019:15), Orhun Abidelerini;

“Türk adının, Türk milletinin isminin geçtiği ilk Türkçe metin. İlk Türk tarihi. Taşlar üzerine yazılmış tarih. Türk devlet adamlarının millete hesap vermesi, milletle hesaplaşması. Devlet milletin karşılıkl vazifeleri. Türk nizamının, Türk töresinin, Türk medeniyetinin, yüksek Türk kültürünün büyük vesikası. Türk askeri dehasının, Türk askerlik sanatının esaslarl. Türk gururunun ilahi yüksekliği. Türk feragat ve faziletinin büyük örneği. Türk ictimai hayatının ulvi tablosu. Türk edebiyatının ilk şaheseri. Türk hitabet sanatının erişilmez şaheseri. Hükümdarane eda ve ihtişamlı hitap tarzı. Yalın ve keskin üslubun şaşırtıcı numunesi. Türk milliyetçiliğinin temel kitabı. Bir kavmi bir millet yapabilecek eser. Asırlar içinden milli istikameti aydınlatan ışık. Türk dilinin mübarek kaynă̆ı. Türk yazı dilinin ilk fakat harikulade işlek örneği. Türk yazı dilinin başlangıcını miladın ilk asırlarına çıkartan delil. Türk ordusunun kuruluşunu en az 1250 sene öteye götüren vesika. Türklü̈̆̈̈n en büyük iftihar vesilesi olan eser. Insanlık aleminin sosyal muhteva bakımından en manalı mezar taşları. Dünyanın bugün belki de en büyük meselesi olan Çin hakkında 1250 sene evvelki Türk ikazı" şeklinde ifade etmiş ve bu abidelerin Türk tarihi, kültürü ve medeniyeti açısından eşsiz bir değere sahip olduğunu vurgulamıştır. 


\section{Sosyal Bilgiler Öğretiminde Değer Eğitimi ve Orhun Abideleri}

Değer kavramı bir varlığın ehemmiyetini belirlemek için soyut bir ölçü, bir şeyin denk geldiği karşılık şeklinde tanımlanabilir (Demir ve Acar, 1992: 82). Bütün milletler, milli benliğini korumak ve geleceğini kendi inançları ve yaşam biçimi özellikleriyle karşılamayı hedeflemektedir. Bu beklentinin gerçek olması ise, yaşayan kuşağın, kendinden önceki kuşaktan aldığı değerleri ve binlerce yıllık milli mirasını, kendinden sonraki kuşaklara aktarımı ve sonraki kuşakların da bu değerleri geliştirip çağına uyan bir işlevsellikte yaşatması ile mümkün olmaktadır (Sever, 2010: 731). Geçmişten gelen değerlerin anılması, yeni içerikler eklenerek zenginleşip, tekrardan hayata katılması o millet için mühim bir güç kaynağı oluşturmaktadır. Bu anlamda, milletin hafızasında saklanmakta olan, toplumları bir arada tutan, maddi ve manevi değerlerin korunarak sonraki kuşaklara öğretilmesi büyük önem arz etmektedir. (Tekşan, 2012: 1). Müthiş bir hızla değişim gösteren hayat koşullarına uyum sağlayabilen, manevi ve milli değerleri içselleştiren, mesleki ve bireysel hayatında başarı sahibi kişiler olunmasına rehberlik etme rolü, eğitim-öğretim kurumlarına yüklenmektedir. Bundan dolayı da eğitim-öğretim kurumları, sadece bilimsel bilgi değil aynı zamanda değerleri de öğreten sistem şeklinde değerlendirilir (Sallabaş, 2012: 61). Bu bağlamda gelecek nesillere değerlerimizin aktarılması sürecinde çeşitli dersler vasıtasıyla okullara belli bir misyon yüklenildiği görülmektedir. Bu derslerin en başında da Sosyal Bilgiler dersi gelmektedir.

Toplumda kişilerin sosyalleşebilmeleri, toplumsal değerleri benimsemeleriyle mümkündür. Sosyal Bilgiler dersinin en önemli gayelerinden biri de bireyin toplumsallaşmasını sağlamaktır. Bu nedenle Sosyal Bilgiler Dersi Öğretim Programlarında II. Meşrutiyet döneminden başlayarak günümüze kadar tüm ilkokul, ortaokul ve ilköğretim okullarında değerler eğitimine yer verilmiştir (Keskin, 2012).

Sosyal Bilgiler Dersi Öğretim Programı (2018) değerlerin, eğitim-öğretim programlarının bakış açısını oluşturan ilkeler toplamı olduğunu vurgular. Bu değerlerin kökleri, geçmişin ve geleneklerin içinde bulunan, dalları ve gövdesi ise bu köklerden beslenip bugüne ve yarınlara ulaşmaktadır. Öz insani nitelikleri oluşturan değerler, yaşamın rutin düzeninde ve önümüze çlkan sorunlarla baş etmede harekete geçmeye yarayan kudret ve gücün kaynağıdır (MEB, 2018: 4). Sosyal Bilgiler Dersi Öğretim Programında (2018) bulunan ve bu araştırmanın da temel unsurunu oluşturan değerler: Bağımsızlık, Adil Olma, Bilimsellik, Aile Birliğini Önemseme, Barışçıl Olma, Çalışkan Olma, Duyarlılık, Dayanışma, Dürüst Olma, Eşitlikçi Yaklaşım, Estetik Yaklaşım, Özgürlük, Sevgi, Saygı, Sorumlu Olma, Vatanseverlik, Tasarruflu Olma, Yardımseverliktir (MEB, 2018: 9).

Çok disiplinli olması, geçmişten günümüze taşınan bir içeriğinin olması, farklı coğrafyaları ve kültürleri konu edinmesi bakımından değerler aktarımında ve iyi vatandaşlar yetiştirme noktasında Sosyal Bilgiler dersi önemli bir yere sahiptir. Sosyal Bilgiler Dersi Öğretim Programının içinde evrensel, ulusal değerlerin yer aldığı görülmüştür. Değerler eğitiminin, sağlıklı toplumların şekillenmesindeki önemi düşünülerek, değerler ve değerler eğitimi uygulamalarındaki araştırmalar arttırılmalı, değerler eğitimine öğretim programlarında ve ders etkinliklerinde daha fazla yer verilmelidir. 
Türk milletine ait ilk yazılı kaynak olarak kabul edilen Orhun Abideleri, Türk milleti açısından günümüzde de ehemmiyet taşıyan değerlere değinmesi, milletimize tavsiye niteliğinde ögütler barındırması bakımından değer eğitimi etkinliklerinde kullanılabilecek kültür abidelerinden birini meydana getirmektedir (Türkmen, 2013: 38). Orhun Abideleri, Türk milletinin kendisini anlatabilmek adına duygu ve düşüncelerinin bir ifadesidir. Bu kitabelerde geçen iyi-kötü yaşam deneyimleri, her yüz yılda yeniden değişmiş ve kuşaktan kuşağa, sözlü ve yazılı eserler vesilesiyle iletilerek günümüze kadar ulaşmıştır (Şenocak, 2001: 166).

Orhun Abidelerinin Türk milletinin ilk yazılı metinleri olarak kabul edilmesi, etkili bir Türkçe ile yazılması, Türk milletinin tarih boyunca yaşattığı değerleri içerisinde barındırması bakımından değerler eğitimi açısından da incelenmesi gerekliliğini ortaya çıkarmıştır. Bu çerçevede araştırmanın amacı, Orhun Abidelerini (Kül Tigin, Bilge Kağan, Tonyukuk) Sosyal Bilgiler Dersi Öğretim Programında yer alan değerler açısından incelemektir. Bu çalışmada “Orhun Abidelerinde Sosyal Bilgiler Dersi Öğretim Programında bulunan hangi değerlere yer verilmiştir?" ve "Orhun Abidelerine Sosyal Bilgiler öğretimi çerçevesinde gerçekleşen değer aktarımı etkinliklerinde yer verilmeli midir?" sorularına cevap aranmiştır.

\section{YÖNTEM}

$\mathrm{Bu}$ araştırmada öncelikle Orhun Abidelerinde Sosyal Bilgiler Dersi Öğretim Programında bulunan değerler ile ilgili alanyazın taranmıştır. Çalışma, nitel araştırma yöntemlerinden doküman incelemesine uygun olarak yapılmıştır. Doküman incelemesi, araştırılması hedeflenen olgu ya da olgularla ilgili bilgi içeren yazılı materyalin analizini kapsar. Tarihçilerin ve arkeologların bir medeniyet veya kültürün geçmişine ait özelliklerini çalışırken kullandıkları en önemli çalışma yöntemlerinden biri, kalıntılardan yola çıkmaktır. Elde ettikleri kalıntıları, belirli bir çerçeve içinde ve birbiri ile ilişkilendirerek ilgili medeniyet ve kültüre ilişkin bütüncül bir resim elde etmeye çalışmaktadırlar (Yıldırım ve Şimşek, 2017). Bu çalışmada, konu ile ilgili en önemli eserlerden olan Muharrem Ergin'in Orhun Abideleri (2019) adlı eseri esas alınmıştır. Araştırmada, bu eser incelenmiş ve araştırma konu ile ilgili diğer eserlerle desteklenmiştir.

\section{Verilerin Toplanması ve Analizi}

Bu çalışmada, Sosyal Bilgiler Dersi Öğretim Programında bulunan değerler çerçevesinde Orhun Abideleri ile ilgili eserler incelenmiştir. Verilerin analizinde içerik analizi kullanılmıştır. İçerik analizi verilerden hareketle görülemeyen, fakat kavramsal kodlama ve sınıflama yolu ile ana fikirlerin ortaya çıkarılması ve bu ana fikirler arasındaki manidar ilişkilerin belirlenmesi sürecidir (Yıldırım ve Şimşek, 2017: 259). Bu analiz kapsamında Sosyal Bilgiler Dersi Öğretim Programında bulunan değerler (Adalet, Aile birliğine önem verme, Bağımsızlık, Barış, Bilimsellik, Çalışkanlık, Dayanışma, Duyarlılık, Dürüstlük, Estetik, Eşitlik, Özgürlük, Saygı, Sevgi, Sorumluluk, Tasarruf, Vatanseverlik, Yardımseverlik) listesi hazırlanmış ve Orhun Abidelerinde bu değerlere karşılık gelen ifadeler belirlenmiştir. Daha sonra bunlar uzman görüşüne sunulmuş, uzman görüşü doğrultusunda çalışma yapılmıştır. 
Araştırma bulguları verilirken abidelerden değerlere ait ifadeler doğrudan alıntı şeklinde aktarılmıştır. Bulgularda abidelere ait alıntılarda verilen kodlamalar Ergin'in (2019) eseri dikkate alınarak belirlenmiştir. Araştırmada “(...)" ifadesi araştırmacının metin içinde yaptığı kısaltmaları bildirmektedir. Abideler incelenirken bazı paragraflarda birden çok değere rastlanmış, aynı paragraf farklı değerler için kaynak gösterilmiştir.

Örneğin;

KT - G - 5 = Kül Tigin Yazıtı- Güney Yüzü- Beşinci Satır

BK - K - 6 = Bilge Kağan Yazıtı- Kuzey Yüzü- Altıncı Satır

T2 - D - 3 = Tonyukuk Yazıtı İkinci Taş- Doğu Yüzü- Üçüncü Satır

KT- D- 12 = Kül Tigin Yazıtı- Doğu Yüzü- On İkinci Satır

\section{BULGULAR}

\section{Adalet/Adil Olma Değeri}

Orhun abidelerinde, toplumda kanun ve adalet kavramlarının karşılığı olarak "töre" kavramını görmekteyiz. Bu dönemde adalet ve kanun yerine geçen töre, insanların doğumundan ölümüne kadar yaşayışlarını şekillendiren toplumsal değerleri oluşturur. Kağanın seçilmesi de dahil toplumsal hayatta birçok durumu etkileyen yazısız kuralları oluşturan töre, herkes için geçerli kabul edilmiştir. Kağanların devleti kurup önce töreyi düzenlemeleri de devlet ve millet için törenin önemini göstermektedir. Devletin başında bulunan kağanlar törenin gerektirdiklerini uygulayarak, devlet ve millet nizamını sağlamayı amaçlamışlardır. Bu da adalet ve düzene verilen önemi göstermektedir. Bu değer yazıtlarda şu ifadelerle anlatılmıştır:

“KT D 1(...) İnsanoğlunun üzerine ecdadım Bumin Kağan, İstemi Kağan oturmuş. Oturarak Türk milletinin ilini töresini tutu vermiş, düzenleyi vermiş. KT D 3 (...) Onun için ili öylece tutmuş tabii. İli tutup töreyi düzenlemiş. Kendisi öylece. KT D 8 (...) Batıda Demir Kapıya kadar ordu sevk edivermiş. Çin Kağanına ilini, töresini alıvermiş. KT D 13 (...) Türk töresini bırakmış milleti, ecdadımın töresince yaratmış, yetiştirmiş. Tölis, Tarduş milletini orda tanzim etmiş. BK D 11, 12 (...) Yedi yüz er olup ilsizleşmiş, kağansızlaşmış milleti, cariye olmuş, kul olmuş milleti, Türk töresini bırakmış milleti ecdadımın töresince yaratmış, yetiştirmiş. Tölis, Tarduş milletini orda tanzim etmiş. Yabguyu, şadı orda vermiş. (...). BK D 14(...) O töre üzerine amcam kağan oturdu. Oturarak Türk milletini tekrar tanzim etti, tekrar besledi. Fakiri zengin kıldı, azı çok kıldı (...)" (Ergin, 2019: 41).

\section{Aile/ Millet Birliği Değeri}

Orhun Abidelerinde hür ve güçlü yaşamanın birlik ve beraberlikle mümkün olacağı ifade edilmiştir. Bir toplumun millet olabilmesi de ortak değerler çerçevesinde birlikte mücadele etmesiyle mümkündür. Aileye verilen önem anlatılırken, esaret altına girildiğinde kadınların korunamayacağı, oğulların kardeşlerini, babalarını bilmez olacağı ve böylece ailenin yok olacağı belirtilmiştir. Ayrıca aile birliğine verilen önemi ve aileye duyulan sevgiyi, aile bireylerinin ölümünden duyulan üzüntü ifadelerinde görmekteyiz. Aile bireylerinin ölümünün ardından hassasiyetle düzenlenen yas törenleri de toplumda ailenin önemini 
göstermektedir. Ayrıca Orhun Abidelerinde başka milletlerle akrabalık bağı kurulduğunu ve aile olmanın barış ortamına sağladığı katkıyı da görmekteyiz. Sonuç olarak yapılan her işte aile kavramı ön planda tutulmuş, aile-millet birliğinin ve yararının gözetilmesi gerektiği anlatılmıştır. Abidelerde bu değer ile ilgili şu ifadelere yer verilmiştir:

"KT K 9 (...) Annem hatun ve analarm, ablalarım, gelinlerim, prenseslerim, bunca yaşayanlar cariye olacaktı, ölenler yurtta yolda yatıp kalacaktınız. KT D 21 (...) Batıda Kengü Tarmana kadar Türk milletini öyle kondurduk, öyle düzene soktuk. O zamanda kul kullu olmuştu. Cariye cariyeli olmuştu. Küçük kardeş büyük kardeşini bilmezdi, oğlu babasını bilmezdi. KT KD 1 Kül Tigin koyun yılında on yedinci günde uçtu. Dokuzuncu ay, yirmi yedinci günde yas töreni tertip ettik (...). KT G 1 (...) Sözümü tamamiyle işit. Bilhassa küçük kardeş yeğenim, oğlum, bütün soyum, milletim, güneydeki şadpıt beyleri, kuzeydeki tarkat, buyruk beyleri, Otuz Tatar... KT D 11 (...) Türk milleti yok olmasin diye, millet olsun diye babam İltiriş Kağan, annem İlbilge Hatunu göğ̈̈n tepesinde tutup yukarı kaldırmış olacak (...) KT D 20, 21 (...) Kağan adını burada biz verdik. Küçük kız kardeşim prensesi verdik. Kendisi yanıldı, kağanı öldü, milleti cariye kul oldu (...). Batıda Kengü Tarmana kadar Türk milletini öyle kondurduk, öyle düzene soktuk. O zamanda kul kullu olmuştu. Cariye cariyeli olmuştu. Küçük kardeş büyük kardeşini bilmezdi, oğlu babasını bilmezdi. KT D 25, 26 (...) Türk milletinin adı sanı yok olmasın diye, babam kağanı, annem hatunu yükseltmiş olan Tanrı, il veren Tanrı, Türk milletinin adı san yok olmasın diye, kendimi o Tanrı kağan oturttu tabii. Varlıkl, zengin millet üzerine oturmadım. İşte aşsız, dışta elbisesiz; düşkün, perişan milletin üzerine oturdum. Küçük kardeşim Kül Tigin ile konuştuk. Babamızın, amcamızın kazanmış olduğu milletin adı sanı yok olmasın. BK G 10 Türküm için, milletim için iyisini öylece kazantverdim. Bu kadar kazanıp babam kă̆an köpek yılı, onuncu ay, yirmi altıda uçup gitti. Domuz yılı, beşinci ay, yirmi yedide yas töreni yaptırdım. BK K 9 Tanrı buyurduğu için kendim oturduğumda dört taraftaki milleti düzene soktum ve tertipledim...kıldım... Türgiş Kağanının kızını fevkalade büyük törenle oğluma alıverdim. T1 K 6, 7 (...) On Ok milleti eksiksiz dışarı çıkmış der. Çin ordusu var imiş. O sözü işitip kağanım, ben eve ineyim dedi. Hatun yok olmuştu. Ona yas töreni yaptırayım dedi (...)" (Ergin, 2019: 59).

\section{Bağımsızlık Değeri}

Bağımsızlık, devletlerin başka devletlerin egemenliğinde olmadan kendi idealleri doğrultusunda geleceğe yürümesidir. Devletin özgürlüğüdür. Türk milleti tarihin her döneminde bağımsız yaşama idealiyle birçok mücadele vermiş, bu uğurda büyük savaşlar yapmış ve bağımsız devletler kurmuştur. Türk milleti verilen bu mücadeleleri ve kahramanlıkları milletine ait birçok eserde işlemiştir. Orhun Abidelerinde de bu mücadeleleri ve elde edilen başarıları görmekteyiz. Hür olmanın onuru, esaretin zorluğu metinlerde sıkça işlenmiştir. Bir milletin hür ve bağımsızlı̆̆ ölçüsünde millet olabildiği vurgulanmıştır. Türk milleti için bağımsızlığın önemini eserde anlatılan hürriyet mücadelelerinden de anlayabilmekteyiz. Orhun Abidelerinde, Türk milletinin bağımsız bir devlet olmanın önemini kavradığını görmekteyiz. Türk milletine ait, Orhun Abideleri gibi bağımsızlık değerini vurgulayan metinleri yeni nesillerimize kavratmak, bu nesillerin devlet ve millet olarak hür olma bilinciyle yetişmelerini sağlayacaktır. Bu değerler ilgili abidelerde şu ifadelere yer verilmiştir:

"KT D 15 Kırk yedi defa ordu sevk etmiş, yirmi savaş yapmış. Tanr lütfettiği için illiyi ilsizletmiş, kă̆anlı̆̆ı kă̆ansızlatmış, düşmanı tabi kılmış, dizliye diz çöktürmüş, başlıya baş e ğdirmiş. KT D 
11(...) Türk milleti yok olmasın diye, millet olsun diye babam İlteriş Kă̆anı, Annem İlbilge Hatunu göğ̈̈n tepesinde tutup yukarı kaldırmış olacak (...). KT D 7 Türk milleti il yaptı̆̆ ilini elden çıkarmış, kağan yaptı̆̆ı kă̆anını kaybedivermiş. Çin milletine beylik erkek evladı kul oldu, hanımlık kız evladı cariye oldu. Türk beyleri Türk adını bıraktı. KT D 18, 19 Yekün olarak yirmi beş defa ordu sevk ettik, on üç defa savaştık. İlliyi ilsizleştirdik, kağanlığ $ı$ kağansızlaştırdık. Dizliye diz çöktürdük, başlıya baş eğgdirdik. Türgiş Kağanı Türkümüz, milletimiz idi. Bilmediği için, bize karşı yanlış hareket ettiği için kağanı öldü. Buyruku, beyleri de öldü. On Ok kavmi eziyet gördü (...). KT D 20, 21, 22, 23(...) Kendisi yamıldı, kă̆anı öldü, milleti cariye, kul oldu. Kögmenin yeri, suyu sahipsiz kalmasın diye Az, Kırgız kavmini düzene sokup geldik. Savaştık... İlini geri verdik Kadırkan ormanını aşarak milleti öyle kondurduk, öyle düzene soktuk. Batıda Kengü Tarmana kadar Türk milletini öyle kondurduk, öyle düzene soktuk. O zamanda kul kullu olmuştu. Cariye cariyeli olmuştu. Küçük kardeş büyük kardeşini bilmezdi, oğlu babasını bilmezdi. Öyle kazanılmış, düzene sokulmuş ilimiz, töremiz vardl. Türk, Oğuz beyleri, milleti işitin: Üstte gök basmasa, altta yer delinmese, Türk milleti ilini töreni kim boza bilecekti? Türk milleti vazgeç, pişman ol! Disiplinsizliğinden dolayı, beslemiş olan bilgili kağanınla, hür ve müstakil iyi iline karşı kendin hata ettin, kötü hale soktun. Silahlı nereden gelip dă̆ıtarak gönderdi? Mizraklı nereden gelerek sürüp gönderdi. Mukaddes Ötüken ormanının milleti, gittin. KT D 29, 30 Tanr bağışlasın, devletim var olduğu için, kısmetim var olduğu için, ölecek milleti diriltip besledim. Çıplak milleti elbiseli, fakir milleti zengin kıldım. Değerli illiden, değerli kă̆anlıdan daha iyi kıldım. Dört taraftaki milleti hep tabii kıldım, düşmansız kıldım. Hep bana itaat etti. İşi gücü veriyor. Bunca töreyi kazanıp küçük kardeşim Kül Tigin kendisi öylece vefat etti (...). KT K 8 Kül Tigin az yağızına binip hücum etti. İki eri mızrakladı. O ordu orda öldü. Amga kalesinde kışlayıp ilkbaharında Oğuza doğru ordu çıkardık. Kül Tigini evin başında bırakarak,

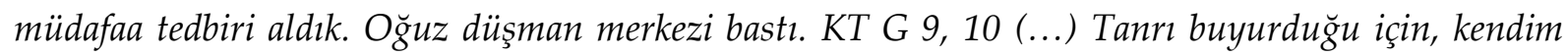
devletli olduğum için, kağan oturdum. Kağan oturup aç, fakir milleti hep toplattım. Fakir milleti zengin kıldım. Az milleti çok kıldım. Yoksa bu sözümde yalan var mı? Türk beyleri, milleti, bunu işitin! Türk milletini toplayıp il tutacağını burada vurdum (...). BK D 7(...) Türk milleti il yaptı̆̆ ilini elden çıkarmış, kağan yaptığı kağanını kaybedivermiş. Çin milletine beylik erkek evladını kul kıldı, hanımlık kız evladını cariye kıldı. Türk beyler Türk adını bıraktı. Çinli beyler Çin adını tutarak, Çin kağanına itaat etmiş. BK D 9,10 Kă̆anl millet idim, kă̆anım hani, ne kağana işi, gücü yeriyorum der imiş. Öyle diyip Çin kağanına düşman olmuş. Bunca işi, gücü vermediğini düşünmeden, Türk milletini öldüreyim, kökünü kurutayım der imiş. Yok olmaya gidiyormuş. Yukarı Türk Tanrısı, mukaddes yeri, suyu öyle tanzim etmiştir. Türk milleti yok olmasın diye, millet olsun diye, babam İltiriş Kağanı, annem İlbilge Hatunu göğün tepesinden tutup yukarı kaldırmıştır. T1 B 15 Bilge Tonyukuk ben kendim Çin ilinde kılındım. Türk milleti Çine tabi idi. Türk milleti hanını bulamayıp Çinden ayrıldı, hanlandı. Hanını bırakıp Çine tekrar teslim oldu. Tanrı şöyle demişsir: Han verdim, hanını bırakıp teslim oldun. Teslim olduğun için Tanrı öldürmüştür. Türk milleti öldü, mahvoldu, yok oldu. Türk Sir milletinin yerinde boy kalmadı. Ormanda taşta kalmış olanı toplanıp yedi yüz oldu. İki kısmı atlı idi, bir kısmı yaya idi. Yedi yüz kişiyi sevk eden büyükleri şad idi. Katıl dedi. Katılanı ben idim. Bilge Tonyukuk. Kağan mı kılayım, dedim." (Ergin, 2019: 45).

\section{Barış Değeri}

Orhun Abidelerinde kağanların bölgelerine nizam getirmek için sorun çıkaran devletleri kendine tabi kılarak düşmanlıkları sonlandırma gayretleri, Çin devleti ile barış antlaşmaları 
yapmaları ve diğer devletlerle de ilişkilerini iyi tutma çabaları barışa verilen önemi göstermektedir. Hakimiyetleri altındaki toplulukları birbirlerine düşman edecek davranışlardan kaçınmaları da barış değerinin önemini göstermektedir. Ayrıca diğer devletlerle evlilik yoluyla kurdukları akrabalık bağları da barış ortamını sağlama ve devam ettirme gayretinin bir başka göstergesi olarak karşımıza çıkmaktadır. Orhun Abidelerinde barış değerine verilen önemi şu ifadelerde görmekteyiz:

“KT G 4,5 (...) Bu yerde oturup Çin milleti ile anlaştım. Altını, gümüşü, ipeği ipekliyi sıkıntısız veriyor. Çin milletinin sözü tatll, ipek kumaşı yumuşak imiş (...). KT D 30 (...) Milleti hep tabi kıldım, düşmansız kıldım. Hep bana itaat etti (...). KT D 27 Türk milleti için gece uyumadım, gündüz oturmadım. Küçük kardeşim Kül Tigin ile, iki şad ile öle yite kazandım. Öyle kazanıp bütün milleti ateş, su kılmadım. KT D 20,21 Kögmenin yeri, suyu sahipsiz kalmasın diye Az, Kırgız kavmini düzene sokup geldik (...). Doğuda Kadırkan ormanını aşarak milleti öyle kondurduk, öyle düzene soktuk. Batıda Kengü Tarmana kadar Türk milletini öyle kondurduk, öyle düzene soktuk. BK D 4 Doğuda Kadırkan ormanına kadar, batıda Demir Kapıya kadar kondurmuş. İkisi arasında pek teşkilatsız Gök Türkü düzene sokarak öylece oturuyormuş. Bilgili kağan imiş, cesur kă̆an imiş. Buyruku bilgili imiş tabii. Cesur imiş tabii. Beyleri de milleti de doğru imiş. Onun için ili öylece tutmuş tabii. İli öylece tutup töreyi düzenlemiş. Kendisi öylece vefat etmiş. BK K 1,2 Tanrr gibi gökte olmuş Türk Bilge Kağanı, bu zamanda oturdum. Sözümü tamamiyle işit. Bilhassa küçük kardeş yeğenim, oğlum, bütün soyum, milletim, güneydeki şadpıt beyleri, kuzeydeki tarkat, buyruk beyleri, Otuz Tatar, ... Dokuz Oğuz beyleri, milleti! Bu sözümü iyice işit, adamakıllı dinle: Doğuda gün doğusuna, güneyde gün ortasına, batıda gün batısına, kuzeyde gece ortasına kadar, onun içindeki millet hep bana tabidir. Bunca milleti hep düzene soktum. O şimdi kötü değildir. Türk Kağanı Ötüken ormanında otursa ilde sıkıntı yoktur. BK K 9 Babam kağan, amcam kağan oturduğunda dört taraftaki milleti nasıl düzene sokmuş... Tanr buyurduğu için kendim oturduğumda dört taraftaki milleti düzene soktum ve tertipledim ... kıldım ... Türgiş kağanına kızımı fevkalade büyük bir törenle aliverdim." (Ergin, 2019: 37).

\section{Bilimsellik Değeri}

Orhun Abidelerinde bilimsellik kavramı daha çok akıl ve tecrübeye dayanarak hareket etme yani bilgelik olarak karşılık bulmuştur. Kağanların, devleti idare edenlerin bilgili olmasının önemine vurgu yapılmış, devletin ve milletin aydınlık geleceğinin bilgili olmakla mümkün olacağı anlatılmıştır. Göktürklerde bilge insanlara ve onların kararlarına duyulan güvenin bir işareti olarak devlet idaresinde bulunan 'Bilge Kağan, Bilge Tonyukuk' isimlerini görmekteyiz. Abidelerde bilgisiz kimselerin kararlarının devleti ve milleti nasıl felakete sürüklediğinden bahsedilmiş, cahilliğin neden olduğu kötü sonuçlara vurgu yapılmıştır. Kağanların ve yardımcılarının devlet ve millet için aldıkları kararlarda ve yaptıkları uygulamalarda bilgi temelli hareket etmelerinin önemi ve gerekliliği ifade edilmiştir. Orhun Abidelerinde bu değerle ilgili şu ifadeleri görmekteyiz:

"KT D 3 (...) Bilgili kağan imiş, cesur kă̆an imiş tabii. Beyleri de milleti de doğru imiş. Onun için ili öylece tutmuş tabii, İli tutup töreyi düzenlemiş (...). KT D 5, 6 (...) Ondan sonra küçük kardeşi büyük kardeşi gibi kılınmamış olacak, oğlu babası gibi kılınmamış olacak. Bilgisiz kağan oturmuştur, kötü kağan oturmuştur. Buyruku da bilgisizmiş tabii, kötü imiş tabii. Beyleri milleti ahenksiz olduğu için, Çin milleti hilekâr ve sahtekar olduğu için, aldatıcı olduğu için, küçük kardeş ve büyük kardeşi 
birbirine düşürdüğ̈̈ için, bey ve milleti karşılıklı çekiştirdiği için, Türk milleti il yaptı̆̆ı ilini elden çıkarmış, kă̆an yaptı̆̆ı kağanını kaybedivermiş. KT G 6,7 İyi bilgili insanı, iyi cesur insanı yürütmezmiş. Bir insan yanılsa, kabilesi, milleti, akrabasına kadar barındırmazmış. Tatlı sözüne, yumuşak ipek kumaşına aldanıp çok Türk milleti, öldün; Türk milleti, öleceksin! Güneyde Çogay ormanına, Tögültün ovasına konayım dersen, Türk milleti öleceksin! Orda kötü kişi şöyle öğretiyormuş: Uzak ise kötü mal verir, yakın ise iyi mal verir deyip öyle öğretiyormuş. Bilgi bilmez kişi o sözü alıp, yakına gidip, çok insan öldün! T1 K 5 Türgiş kağanından casus geldi. Sözü şöyle: Doğuda kağana karşı ordu yürütelim demiş. Yürütmezsek, bizi kağanı kahraman imiş, müşaviri bilici imiş ne zaman bir şey olsa bizi öldürecektir demiş. BK D 4 (...) Bilgili kağan imiş. Cesur kă̆an imiş. Buyruku bilgili imiş tabii. Cesur imiş tabii. Beyleri de milleti de doğru imiş. Onun için ili öylece tutmuş tabii. İli tutup töreyi düzenlemiş." (Ergin, 2019: 41).

\section{Çalışkanlık Değeri}

Orhun Abidelerinde devleti yöneten kağanların devleti için birçok zorlu mücadelelere girdikleri ve çok çalışarak milletin refahı için uğraştıklarını görmekteyiz. Abidelerde kağanların devletin ve milletin tehlikeye düştüğü anlarda kendi rahatlarını düşünmeden, hiç durmadan milletin varlığı için gayret ettiklerini ve zorda olan halka her zaman yardım ederek, sahip çıkmaya çalıştıklarını görmekteyiz. Kağanlar devletin ve milletin refahı için mücadele etmeyi bir görev bilmişler ve bu mücadelenin kutsiyetine inanmışlardır. Orhun Abidelerinde çalışkanlık değeri ile ilgili şu ifadeler yer almaktadır:

“T2 D 1,2 (...) Kapgan Kă̆an yirmi yedi yaşında... orda... idi. Kapgan Kağan oturdu. Gece uyumadı. Gündüz oturmadı. Kızıl kanımı döktürerek, kara terimi koşturarak işi gücü verdim hep. Uzun keşif kolunu yine gönderdim hep. KT D 27 (...) Türk milleti için gece uyumadım, gündüz oturmadım. Küçük kardeşim Kül Tigin ile iki şad ile öle yite kazandım. Öyle kazanıp bütün milleti ateş, su kılmadım (...). KT D 8 Doğuda gün doğusunda Bökli kă̆ana kadar ordu sevk edivermiş. Çin kă̆anına ilini, töresini alıvermiş. KT D 29,30 Tanrı bağışlasın devleti var olduğu için, kısmetim var olduğu için, ölecek milleti diriltip besledim. Çıplak milleti elbiseli, fakir milleti zengin kıldım. Az milleti çok kıldım. Değerli illiden, değerli kağanlıdan daha iyi kıldım. Dört taraftaki milleti hep tabii kıldım, düşmansız kıldım. Hep bana itaat etti. İşi gücü veriyor. KT D 18 Yekün olarak yirmi beş defa ordu sevk ettik, on üç defa savaştık. İlliyi ilsizleştirdik, kağanlıyı kağansızlaştırdık. Dizliye diz çöktürdük. Başlıya baş eğgirdik. KT D 16 (...) Amcam kă̆an oturarak Türk milletini tekrar tanzim etti, besledi. Fakiri zengin kıldı, azı çok kıldı. KT G 10 Kağan oturup aç, fakir milleti hep toplattım. Fakir milleti zengin kıldım. Az milleti çok kıldım (...). BK K 9 Babam kă̆an, amcam kă̆an oturduğunda dört taraftaki milleti nasıl düzene sokmuş ... Tanrı buyurduğu için kendim oturduğumda dört taraftaki milleti düzene soktum ve tertipledim. BK K 7 Tanrı buyurduğu için, kendim devletli olduğum için kağan oturdum. Kă̆an oturup aç, fakir milleti hep toplattım. Fakir milleti zengin kıldım. Az milleti çok kıldım. T1 G 1 Geyik yiyerek, tavşan yiyerek oturuyorduk. Milletin boğazı tok idi. Düşmanımız etrafta ocak gibi idi. Biz ateş idik (...)" (Ergin,2019: 111).

\section{Dayanışma Değeri}

Orhun Abidelerinde kağanların halkından ihtiyaç sahiplerine yardım etmek için yaptıkları mücadele ve milletin refahı için gösterdikleri azim toplumda dayanışmanın en büyük 
örneklerini sunmaktadır. Bilge Kağan ile kardeşi Kül Tigin devletin ve milletin varlığının devamı için düşmanlarına karşı birlikte mücadele etmişler ve büyük bir dayanışma örneği göstermişlerdir. Devletin ve milletinin selameti için Türk kağanlarının ve milletinin varlıkta ve yoklukta hep beraber verdikleri mücadele dayanışma değerinin toplumdaki yerini ve önemini göstermektedir. Orhun Abidelerinde bu değerle ilgili şu ifadeleri görmekteyiz:

“KT D 29 (...) Tanrı bağışlasın, devletim var olduğu için, kısmetim var olduğu için, ölecek milleti diriltip besledim. Çıplak milleti elbiseli, fakir milleti zengin kıldım. Az milleti çok kıldım (...). BK D 21,22 (...) Küçük kardeşim Kül Tigin iki şad, küçük kardeşim Kül Tigin ile konuştuk. Babamızın amcamızın kazanmış olduğu milletin adı sanı yok olmasın diye Türk milleti için gece uyuyamadım, gündüz oturmadım (...). KT G 10 Kağan oturup aç, fakir milleti hep toplattım. Fakir milleti zengin kıldım. Az milleti çok kıldım. KT D 16 (...) O töre üzerine kă̆an oturdu. Amcam kağan oturarak Türk milletini tekrar tanzim etti, besledi. Fakiri zengin kıldı, azı çok kıldı. KT D 21, 22 (...) Doğuda Kadırkan ormanın aşarak milleti öyle kondurduk, öyle düzene soktuk. Batıda Kengü Tarmana kadar Türk milletini öyle kondurduk, öyle düzene soktuk. (...) Öyle kazanılmış, düzene sokulmuş ilimiz, töremiz vardı. KT D 28. Ben kendim kağan oturduğumda, her eyere gitmiş olan millet öle yite, yaya olarak çılak olarak dönüp geldi. Milleti besleyeyim diye, kuzeyde Oğuz kavmine doğru, doğuda Kıtay, Tatabı kavmine doğru, güneyde Çine doğru on iki defa büyük ordu sevk ettim. KT D 26, 27 Varlıkl, zengin millet üzerine oturmadım. İşte aşsız, dışta elbisesiz; düşkün perişan milletin üzerine oturdum. Küçük kardeşim Kül Tigin ile konuştuk. Babamızın, amcamızın kazanmış olduğu milletin adı sanı yok olmasın diye, Türk milleti için gece uyumadım, gündüz oturmadım. Küçük kardeşim Kül Tigin ile iki şad ile öle yite kazandım. Öyle kazanıp bütün milleti ateş, su kılmadım. T1 G 1 Geyik yiyerek, tavşan yiyerek oturuyorduk. Milletin boğazı tok idi. Düşmanımız etrafta ocak gibi idi, biz ateş idik." (Ergin, 2019: 51).

\section{Duyarlılık Değeri}

Orhun Abidelerinde devletin karışıklık içine düştüğü anlarda kağanların büyük bir gayret gösterdikleri ve sıkıntıları bertaraf etmek için mücadele ettikleri anlatılmıştır. Kağanlar büyük bir hassasiyetle halkının zor zamanlarında onları korumak ve refah içerisinde olmaları için büyük gayretler göstermişlerdir. Devleti idare edenlerin devletine ve milletine duydukları derin sevgiyi milletin varlığını devam ettirmek için verdikleri büyük mücadelede görmekteyiz. Devletin tehlike altında olduğunu hissettikleri zamanlarda kağanların ifadeleri duyarlılığın en güzel örneklerindendir. Ayrıca Kağanların kardeşlerinin ölümü üzerine duydukları üzüntüyü anlatan ifadeleri ve onlar için yaptırdıkları törenler de duyarlılığın bir başka örneğidir. Orhun Abidelerinde duyarlılık değeri ile ilgili ifadeler şöyledir:

“KT K 11 (...) Öyle düşünceye daldım. Gözden yaş gelse mâni olarak, gönülden ağlamak gelse geri çevirerek düşünceye daldım. Müthiş düşünceye daldım (...). T1 D 5 (...) Türk milleti yine karışıklık içindedir demiş. Oğuzu yine dardadır demiş. Bu sözü işitip gece yine uyuyacağım gelmiyordu. KT D 9 Türk halk kitlesi şöyle demiş: Illi millet idim, ilim şimdi hani, kime ili kazanıyorum der imiş. Kağanl millet idim, kağanım hani, ne kağana işi gücü veriyorum der imiş. KT G 9 Hep orda mahvoldun, yok edildin. Orda geri kalanınla her yere hep zayıflayarak, ölerek yürüyordun. T1 G 2-5 Casusun sözü şöyle: Dokuz Oğuz milletinin üzerine kağan oturdu der. Çine doğru Ku'yu, generali göndermiş. Kıtaya doğru Tongra Esimi göndermiş, sözü şöyle göndermiş: Azıcık Türk milleti yürüyormuş; kağanı cesur imiş, müşaviri bilici imiş; o iki kişi var olursa seni, Çini öldürecek derim; 
doğuda Kıtayı öldürecek derim; beni, Oğuzu da öldürecek derim; Çin, güney taraftan hücum et; ben kuey taraftan hücum edeyim; Türk Sir milleti, yerinde hiç yürümesin; mümkünse hep yok edelim derim. O sözü işitip gece uyuyacă̆ım gelmedi, gündüz oturacă̆ım gelmedi (...)" (Ergin, 2019: 61).

\section{Dürüstlük Değeri}

Orhun Abidelerinde kağanların yalan söylememek üzerinde sıkça durdukları, beylerin ve milletin doğruluk üzere olduğuna vurgu yapılmıştır. Orhun Abidelerinde Çin devletinin yalan üzerine kurulu bir politikayla Türk milletine büyük zararlar vermeye çalıştığı ve Türklerin bunlara aldanmayarak varlığını devam ettirebileceği ifade edilmiştir. Abidelerde Türk devletinin ve töresinin varlığının devamı milletin ve devleti yönetenlerin doğruluk, dürüstlük değerlerine bağlılığının bir sonucu kabul edilmiştir. Ayrıca Orhun Abidelerinde kağanların devleti için verdiği mücadeleyi büyük bir açık yüreklilikle anlatması bir anlamda milletine hesap vermesi de dürüstlüğün önemli bir göstergesidir. Yazıtlarda bu değerle ilgili şu ifadelere yer verilmiştir:

“KT G 10 (...) Az milleti çok kıldım. Yoksa bu sözümde yalan var mı? Türk beyleri, milleti bunu işitin! (...). KT D 3 (...) Bilgili kağan imiş, cesur kă̆an imiş. Buyruku yine bilgili imiş tabii. Beyleri de milleti de doğru imiş (...). KT G 5-7 Çin milleti ile anlaştım. Altını, gümüşü, ipeği ipekliyi sıkıntısız öylece veriyor. Çin milletinin sözü tatlı, ipek kumaşı yumuşak imiş. Tatlı sözle, yumuşak ipek kumaşla aldatıp uzak milleti öylece yaklaştırırmış. Yaklaştırıp, konduktan sonra, kötü şeyleri o zaman düşünürmüş. İyi bilgili insanı, iyi cesur insanı yürütmezmiş. Bir insan yanılsa, kabilesi, milleti, akrabasına kadar barındırmazmış. Tatlı sözüne, yumuşak ipek kumaşına aldanıp çok çok, Türk milleti, öldün; Türk milleti, öleceksin! Güneyde Çogay ormanına, Tögültün ovasına konayım dersen, Türk milleti öleceksin! Orda kötü kişi şöyle öğretiyormuş: Uzak ise kötü mal verir, yakın ise iyi mal verir diyip öyle öğretiyormuş. Bilgi bilmez kişi o sözü alıp, yakına gidip, çok insan, öldün! BK K 7 Kağan oturup aç, fakir milleti hep toplattım. Fakir milleti zengin kıldım. Az milleti çok kıldım. Yoksa bu sözümde yalan var mı?" (Ergin, 2019: 39).

\section{Estetik Değeri}

Orhun Abidelerinde kağanların devlet ve milletle ilgili düşüncelerini kitabelere yazdırmaları ve bu kitabelerde atasözü, deyim, benzetme gibi söz sanatlarının kullanılmasıyla oluşan anlatım zenginliği edebi ve estetik bakımdan yüksek bir değere işaret etmektedir. Çin'den özel sanatkarların, mezar taşı, türbe yapımı ve bunlar üzerine resim yapılması ile ilgili davet edilerek, ölen kişinin ardından yaptırılan sanatsal anıt mezarlar da estetik değerinin önemli bir göstergesidir. Bunun bir örneği olarak Kül Tigin Abidesi ve türbesinin inşasında Türk ve Çinli sanatkarların birlikte çalıştığının ifade edilmesini gösterebiliriz. Orhun Kitabelerinde estetik değeri ile ilgili şu ifadeler yer almaktadır:

“KT K 13 (...) Kırgız kă̆anından Tarduş İnançu Çor geldi. Türbe yapıcı, resim yapan, kitabe taşı yapıcısı olarak Çin kă̆anının yeğgni Çang general geldi. KT G 11-12 (...) Ben ebedi taş yontturdum ... Çin kağanından resimci getirdim, resimlettim. Benim sözümü kırmadı. Çin kağanının maiyetindeki resimciyi gönderdi. Ona bambaşka türbe yaptırdım. İçine dışına bambaşka resim vurdurdum. Taş yontturdum. Gönüldeki sözümü vurdurdum ... On ok oğluna, yabancina kadar bunu görüp bilin. Ebedi taş yontturdum. KT KD 1 Kül Tigin koyun yllında on yedinci günde uçtu. 
Dokuzuncu ay, yirmi yedinci günde yas töreni tertip ettik. Türbesini, resmini, kitabe taşını maymun yılında yedinci ay, yirmi yedinci günde hep bitirdik. Kül Tigin kendisi kırk yedi yaşında bulut çöktürdü ... Bunca resimciyi Tuygut vali getirdi. BK GB 1 Bilge Kağan kitabesini Yollug Tigin, yazdım. Bunca türbeyi, resimi, sanatı ... kağanın yeğeni Yollug Tigin ben bir ay dört gün oturup yazdım, resimledim. BK K 14, 15 (...) Ondan sonra Çin kă̆anından resimciyi hep getirttim. Benim sözümü kırmadı. Maiyetindeki resimciyi gönderdi. Ona bambaşka türbe yaptırdım. İçine dışına bambaşka resim vurdurdum. Taş yontturdum. Gönüldeki sözümü vurdurdum. On Ok oğluna, yabancıya kadar bunu görüp bilin! Ebedi taş yontturdum... yontturdum, yazdırdım ... O taş türbesini ..." (Ergin, 2019: 61).

\section{Eşitlik Değeri}

Orhun Yazıtlarında, kağanların milletini bir bütün halinde gördüğü, hepsinin ihtiyaçlarını giderme gayesinde olduğu ve halkına eşit yaklaştığını görmekteyiz. Kağanların devleti ve milleti idare ederken töreye ve toplum değerlerine bağlı kaldığını ve onları koruma ve onlara yardım etme noktasında eşitlikçi bir yaklaşım benimsediğini görmekteyiz. Orhun Abidelerinde eşitlik değeri ile ilgili şu ifadelere yer verilmiştir:

“KT G 10 (...) Kağan oturup aç, fakir milleti hep toplattım. Fakir milleti zengin kıldım. Az milleti çok kıldım. Yoksa bu sözümde yalan var mı? (...). BK D 14 O töre üzerine amcam kağan oturdu. Oturarak Türk milletini tekrar tanzim etti, tekrar besledi. Fakiri zengin kıldı, azı çok kıldı (...). BK D 23 (...) Ondan sonra Tanrı buyurduğu için, devletim, kısmetim var olduğu için, ölecek milleti diriltip besledim. Çıplak milleti elbiseli kıldım. Fakir milleti zengin kıldım. KT D 16 (...) Amcam kağan oturarak Türk milletini tekrar tanzim etti, besledi. Fakiri zengin kıldı, azı çok kıldı. KT D 29 Tanrı bağışlasın, devletim var olduğu için, kısmetim var olduğu için, ölecek milleti diriltip besledim. Çıplak milleti elbiseli, fakir milleti zengin kıldım. Az milleti çok kıldım (...)." (Ergin, 2019: 39).

\section{Özgürlük Değeri}

Özgürlük, bireylerin esaret altından olmadan kendi istek ve amaçları doğrultusunda yaşamasıdır. Devletin özgür olması ise bağımsızlıktır. Orhun Abidelerinde, esaret altında yaşamanın millet için dayanılmaz sonuçlarına yer verilmiş, özgür yaşamanın tarih boyunca Türk milletinin en büyük özelliği olduğu vurgulanmıştır. Esaret altında kalmadan hür bir millet olarak yaşamanın gerekliliği abidelerde sıkça karşımıza çıkmaktadır. Orhun Abidelerinde, Türk milletinin birlik ve beraberlik içerisinde devletinin ve milletinin istiklali için her türlü zorluğa katlanması ve hürriyet mücadelesi anlatılmıştır. Türk milleti özgürlüğü için verdiği mücadeleleri ve kahramanlıkları eserlerinde işlemiştir. Bu şekilde millet olarak hür yaşamanın gerekliliğini ifade eden ve gelecek nesillerimizin bu bilinçle yetişmelerini sağlayacak eserlerin incelenmesi büyük önem arz etmektedir. Abidelerde bu değere yönelik şu ifadeler bulunmaktadır:

"KT D 15 Kırk yedi defa ordu sevk etmiş, yirmi savaş yapmış. Tanrı lütfettiği için illiyi ilsizletmiş, kă̆anlığı kă̆ansızlatmış, düşmanı tabi kılmış, dizliye diz çöktürmüş, başlıya baş eğdirmiş. KT D 11(...) Türk milleti yok olmasın diye, millet olsun diye babam İlteriş Kağanı, Annem İlbilge Hatunu göğün tepesinde tutup yukarı kaldırmış olacak (...). KT D 7 Türk milleti il yaptı̆̆ı ilini elden çıkarmış, kağan yaptı̆̆ı kă̆anını kaybedivermiş. Çin milletine beylik erkek evladı kul oldu, hanımlık 
kız evladı cariye oldu. Türk beyler Türk adını bıraktı. KT D 18, 19 Yekün olarak yirmi beş defa ordu sevk ettik, on üç defa savaştık. Illityi ilsizleştirdik, kă̆anlı̆̆ı kağansızlaştırdık. Dizliye diz çöktürdük, başlıya baş eğdirdik. Türgiş Kağanı Türkümüz, milletimiz idi. Bilmediği için, bize karşı yanlış hareket ettiği için kağanı öldü. Buyruku, beyleri de öldü. On Ok kavmi eziyet gördü (...). KT D 20, 21, 22, 23(...) Kendisi yanıldı, kağanı öldü, milleti cariye, kul oldu. Kögmenin yeri, suyu sahipsiz kalmasın diye Az, Kırgız kavmini düzene sokup geldik. Savaştık...ilini geri verdik Kadırkan ormanını aşarak milleti öyle kondurduk, öyle düzene soktuk. Batıda Kengü Tarmana kadar Türk milletini öyle kondurduk, öyle düzene soktuk. O zamanda kul kullu olmuştu. Cariye cariyeli olmuştu. Küçük kardeş büyük kardeşini bilmezdi, oğlu babasını bilmezdi. Öyle kazanılmış, düzene sokulmuş ilimiz, töremiz vardl. Türk, Oğuz beyleri, milleti işitin: Üstte gök basmasa, altta yer delinmese, Türk milleti ilini töreni kim boza bilecekti? Türk milleti vazgeç pişman ol! Disiplinsizliğinden dolayı, beslemiş olan bilgili kağanınla, hür ve müstakil iyi iline karşı kendin hata ettin, kötü hale soktun. Silahl nereden gelip dağıtarak gönderdi? Mizraklı nereden gelerek sürüp gönderdi. Mukaddes Ötüken ormanının milleti, gittin. KT D 29, 30 Tanrı bağışlasın, devletim var olduğu için, kısmetim var olduğu için, ölecek milleti diriltip besledim. Çıplak milleti elbiseli, fakir milleti zengin kıldım. Değerli illiden, değerli kağanlıdan daha iyi kıldım. Dört taraftaki milleti hep tabii kıldım, düşmansız kıldım. Hep bana itaat etti. Isşi gücü veriyor. Bunca töreyi kazanıp küçük kardeşim Kül Tigin kendisi öylece vefat etti (...). KT K 8 Kül Tigin az yağızına binip hücum etti. İki eri mızrakladı. O ordu orda öldü. Amga kalesinde kışlayıp ilk baharında Oğuza doğru ordu çıkardık. Kül Tigini evin başında bırakarak,

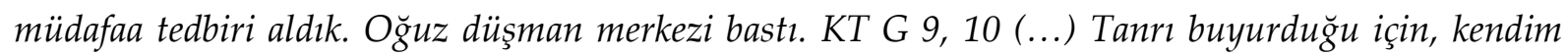
devletli olduğum için, kağan oturdum. Kağan oturup aç, fakir milleti hep toplattım. Fakir milleti zengin kıldım. Az milleti çok kıldım. Yoksa bu sözümde yalan var mı? Türk beyleri, milleti, bunu işitin! Türk milletini toplayıp il tutacağını burada vurdum (...). BK D 7(...) Türk milleti il yaptığı ilini elden çıkarmış, kağan yaptığı kağanını kaybedivermiş. Çin milletine beylik erkek evladını kul kıldı, hanımlık kız evladını cariye kıldı. Türk beyler Türk adını bıraktı. Çinli beyler Çin adını tutarak, Çin kağanına itaat etmiş. BK D 9,10 Kă̆anlı millet idim, kağanım hani, ne kă̆ana işi, gücü yeriyorum der imiş. Öyle diyip Çin kağanına düşman olmuş. Bunca işi, gücü vermediğini düşünmeden, Türk milletini öldüreyim, kökünü kurutayım der imiş. Yok olmaya gidiyormuş. Yukarı Türk Tanrısı, mukaddes yeri, suyu öyle tanzim etmiştir. Türk milleti yok olmasın diye, millet olsun diye, babam İlteriş kă̆anı, annem İlbilge Hatunu göğün tepesinden tutup yukarı kaldırmıştır. T1 B 15 Bilge Tonyukuk ben kendim Çin ilinde kılındım. Türk milleti Çine tabi idi. Türk milleti hanını bulamayıp Çinden ayrıldı, hanlandı. Hanını bırakıp Çine tekrar teslim oldu. Tanrı şöyle demiştir: Han verdim, hanını bırakıp teslim oldun. Teslim olduğun için Tanrı öldürmüştür. Türk milleti öldü, mahvoldu, yok oldu. Türk Sir milletinin yerinde boy kalmadı. Ormanda taşta kalmış olanı toplanıp yedi yüz oldu. İki kısmı atlı idi, bir kısmı yaya idi. Yedi yüz kişiyi sevk eden büyükleri şad idi. Katıl dedi. Katılanı ben idim. Bilge Tonyukuk. Kağan mı kılayım, dedim." (Ergin, 2019: 45).

\section{Sayg1 Değeri}

Orhun Abidelerinde kağana duyulan sonsuz saygı birçok bölümde göze çarpmaktadır. Kül Tigin'in milleti ve diğer uluslar tarafından değerli bir devlet adamı olarak görüldüğü, ölümünün ardından yapılan cenaze merasiminden, milletinin ve diğer devlet büyüklerinin gösterdiği derin saygıdan anlaşılmaktadır. Türk toplumlarında aile yapısının korunması ve sosyal yaşamda düzenin sağlanması adına saygı kavramına büyük önem atfedilmiştir. 
Ailenin ve toplumun büyüklerine gösterilen saygının, devlet ve millet nizamının devamı açısından gerekliliğine inanılmaktadır. Orhun Abidelerinde saygı değeri ifadelerde yer almaktadır:

“KT D 4 (...) Yasçı, ăglayıcı, doğuda gün doğusundan halk, Çin, Tibet, Avar, Bizans, Kırgız, Üç Kurıkan, Otuz Tatar, Kıtay, Tatabı bunca millet gelip ă̆lamış, yas tutmuş. Öyle ünlü kağan imiş (...). KT G 11 (...) Her ne sözüm varsa ebedi taşa vurdum. Ona bakarak bilin. Şimdiki Türk milleti, beyleri, bu zamanda itaat eden beyler olarak mı yanılacaksını? (...). KT D 16 Babam kağan öylece ili, töreyi kazanıp, uçup gitmiş. Babam kağan için ilkin Baz Kağanı balbal olarak dikmiş. O töre üzerine kağan oturmuş. KT D 21 (...) O zaman da kul kullu olmuştu. Cariye cariyeli olmuştu. Küçük kardeş büyük kardeşini bilmezdi, oğlu babasını bilmezdi. KT K 10-13 Küçük kardeşim Kül Tigin vefat etti. Kendim düşünceye daldım. Görür gözüm görmez gibi, bilir aklım bilmez gibi oldu. Kendim düşünceye daldım. Zamanı Tanrı yaşar. İnsanoğlu hep ölmek için türemiş. Öyle düşünceye daldım. Gözden yaş gelse mâni olarak, gönülden ağlamak gelse geri çevirerek düşünceye daldım. Müthiş düşünceye daldım. İki şadın ve küçük kardeş yeğenimin, oğlumun, beylerimin, milletimin gözü kaşı kötü olacak diyip düşünceye daldım. Yasçı, ağlayıcı olarak Kıtay, Tatabı milletinden başka Udar general geldi. Çin kağanından İsiyi Likeng geldi. On binlik hazine, altın, gümüş fazla fazla getirdi. Tibet kağanından vezir geldi. Batıda gün batısındaki Soğd, İranl, Buhara ülkesi halkından Enik general, Oğul Tarkan geldi. On Ok oğlum Türgiş kağanından Makaraç mühürdar, Oğuz Bilge mühürdar geldi. Kırgız kă̆anından Tarduş İnançu Çor geldi. Türbe yapıcı, resim yapan, kitabe taşı yapıcısı olarak Çin kağanının yeğeni Çang general geldi. BK K 13 Türk beylerini, milletini ... besleyin, zahmet çektirmeyin, incitmeyin!" (Ergin, 2019: 41).

\section{Sevgi Değeri}

Orhun Kitabelerinde devlete ve millete duyulan derin sevgi, ülkenin dara düştüğü zamanlarda duyulan üzüntü ve milletin selameti için yapılan mücadelelerde büyük ölçüde hissedilmektedir. Kağanın ölümünün ardından duyulan üzüntü de toplumda aileye duyulan sevginin bir yansımasıdır. Bilge Kağan'ın ölümünün ardından oğlunun duyduğu derin üzüntüde baba sevgisini, Bilge Kağan'ın kardeşi Kül Tigin'in ölümü üzerine ifade ettiği duyguları da kardeş sevgisinin en güzel örneklerindendir. Kitabelerde sevgi değeri, vatanmillet sevgisi ve aile sevgisi olarak karşımıza çıkmaktadır. Bu değerle ilgili şu ifadelere yer verilmiştir:

“KT K 10, 11(...) Küçük kardeşim Kül Tigin vefat etti. Kendim düşünceye daldım. Görür gözüm görmez gibi, bilir aklım bilmez gibi oldu. Kendim düşünceye daldım. Zamanı Tanrı yaşar. İnsanoğlu hep ölmek için türemiş. Öyle düşünceye daldım. Gözden yaş gelse mâni olarak, gönülden ağlamak gelse geri çevirerek düşünceye daldım. Müthiş düşünceye daldım. İki şadın ve küçük kardeş yeğenimin, oğlumun, beylerimin, milletimin gözü kaşı kötü olacak diyip düşünceye daldım (...). KT D 4 (...) Yasçı, ă̆layıcı, doğuda gün doğusundan Bökli Çöllü halk, Çin, Tibet, Avar, Bizans, Kırgız, Üç Kurıkan, Otuz Tatar, Kıtay, Tatabı bunca millet gelip ă̆lamış, yas tutmuş (...). BK D 5 Yasçı, ă̆layıcl, doğuda gün doğusundan Bökli Çöllü halk, Çin, Tibet, Avar, Bizans, Kırgız, Üç Kurıkan, Otuz Tatar, Kıtay, Tatabı, bunca millet gelip ağlamış, yas tutmuş (...). BK G 10 (...) Bu kadar kazanı babam kă̆an köpek yıl, onuncu ay, yirmi altıda uçup gitti. Domuz yıll, beşinci ay, yirmi yedide yas töreni yaptırdım (...). BK B 2-6 Bilge Kağan uçtu. Yaz olsa, üstte gök davulu gürler gibi, öylece ve dă̆da yabani geyik gürlese, öylece mateme gark oluyorum (...)" (Ergin, 2019: 59). 


\section{Sorumluluk Değeri}

Orhun Kitabelerinde, kağanların devletine ve halkına karşı sorumluluklarının farkında olduğu, halkının ihtiyaçlarını gidermek, devletin ve milletin nizamı için mücadele ettikleri anlaşılmaktadır. Devletinin ve milletin her türlü derdiyle dertlendiklerini, milletinin hür ve refah içinde yaşaması için kendilerini hep sorumlu hissettiklerini görmekteyiz. Geçmişte olduğu gibi günümüzde de bireylerin kendisine, ailesine ve milletine karşı olan sorumluluklarının bilincinde olması ve yerine getirmesi bakımından bu değeri yansıtan eserlerimiz büyük önem arz etmektedir. Abidelerde, bu değerle ilgili şu ifadelere yer verilmiştir:

“KT D 1-3(...) İnsanoğlunun üzerine ecdadım Bumin Kă̆an, İstemi Kağan oturmuş. Oturarak Türk milletinin ilini, töresini tutu vermiş, düzenleyivermiş. Dört taraf hep düşman imiş. Ordu sevk ederek dört taraftaki milleti hep almış, hep tabi kılmış. Başlıya baş eğdirmiş, dizliye diz çöktürmüş. Doğuda Kudırkan ormanına kadar, batıda Demir Kapıya kadar kondurmuş. İkisi arasında pek teşkilatsız Gök Türk öylece oturuyormuş. Bilgili Kağan imiş, cesur kağan imiş tabii. Beyleri de milleti de doğru imiş. Onun için ili öylece tutmuş tabii. İli tutup töreyi düzenlemiş (...). BK D 36, 37 (...) Bu yerde bana kul oldu. Ben kendim kağan oturduğum için Türk milletini ... kılmadım. İlini, töreyi çok iyi kazandım ... toplanıp ... orda savaştım. Askerini mızrakladım. Teslim olan teslim oldu, millet oldu; Ölen öldü (...). KT G 9,10 Öyle olduğun için beslemiş olan kağanının sözünü almadan her yere gittin. Hep orada mahvoldun, yok edildin. Orda geri kalanınla her yere hep zayıflayarak, ölerek yürüyordun. Tanrı buyurduğu için, kendim devletli olduğum için, kă̆an oturdum. Kağan oturup aç, fakir milleti hep toplattım. Fakir milleti zengin kıldım. Az milleti çok kıldım. KT D 15 Kırk yedi defa ordu sevk etmiş, yirmi savaş yapmış. Tanrı lütfettiği için illiyi ilsizletmiş, kă̆anlıyı kağansızlatmış, düşmanı tabi kılmış, dizliye diz çöktürmüş, başlıya baş eğdirmiş. Babam kağan öylece ili, töreyi kazanıp, uçup gitmiş (...). KT D 27-30 Türk milleti için gece uyumadım, gündüz oturmadım. Küçük kardeşim Kül Tigin ile iki şad ile öle yite kazandım. Öyle kazanıp bütün milleti ateş, su kılmadım. Ben kendim kă̆an oturduğumda her yere gitmiş olan millet öle yite, yaya olarak çılak olarak dönüp geldi. Milleti besleyeyim diye, kuzeyde Oğuz kavmine doğru, doğuda Kıtay, Tatabı kavmine doğru, güneyde Çine doğru on iki defa büyük ordu sevk ettim, ... savaştım. Ondan sonra Tanrı bağışlasın, devletim var olduğu için, kısmetim var olduğu için, ölecek milleti diriltip besledim. Çılak milleti elbiseli, fakir milleti zengin kıldım. Az milleti çok kıldım. Değerli illiden, değerli kă̆anlıdan daha iyi kıldım. Dört taraftaki milleti hep tabi kıldım. Düşmansız kıldım. Hep bana itaat etti (...). BK D 22-24 (..) Babamızın amcamızın kazanmış olduğu milletin adı sanı yok olmasın diye Türk milleti için gece uyuyamadım, gündüz oturmadım. Küçük kardeşim Kül Tigin ile iki şad ile öle yite kazandım. Öyle kazanıp bütün milleti ateş, su kılmadım. Ben kendim kağan oturduğumdan her yere gitmiş olan millet, yaya olarak, çılak olarak, öle yite geri geldi. Milleti besleyeyim diye kuzeyde Oğuz kavmine doğru; doğuda Kıtay, Tatabı kavmine doğru; güneyde Çine doğru on iki defa ordu sevk ettim ... savaştım. Ondan sonra Tanrı buyurduğu için, devletim, kısmetim var olduğu için, ölecek milleti diriltip besledim. Çıplak milleti elbiseli kıldım. Fakir milleti zengin kıldım. Az milleti çok kıldım. Değgrli illiden, değerli kağanlıdan daha iyi kıldım. Dört taraftaki milleti hep tabi kıldım, düşmansız kıldım. Hep bana itaat etti (...)" (Ergin, 2019: 41).

\section{Tasarruf Değeri}


Orhun Yazıtlarında kağanlar, halkına yokluğun zorluğunu anlatmakta, bolluk ve refah içinde olunan dönemlerin geçebileceğini, devletin ve milletin dara düşebileceğini bu yüzden hür olmanın ve sahip oldukları varlığın kıymetini bilmeleri gerektiğini salık vermektedirler. Orhun Kitabelerinde bu değerle ilgili ifadeler şunlardır:

"KT G 8 (...) Türk milleti, tokluğun klymetini bilmezsin. Açlık, tokluk düşünmezsin. Bir doysan açlı̆̆ı düşünmezsin. Öyle olduğun için, beslemiş olan kağanının sözünü almadan her yere gittin (...)" (Ergin, 2019: 37).

\section{Vatanseverlik Değeri}

Orhun Abideleri incelendiğinde anlatının tamamında vatan-millet sevgisinin hâkim olduğu görülür. Kağanların vatanın ve milletin menfaati için girdiği mücadeleler buna en güzel örnektir. Kitabelerde bu değere yönelik şu ifadeler yer alır:

“BK G 10 (...) Türküm için, milletim için iyisini öylece kazanı verdim. O kadar kazanıp babam kă̆an köpek yıll, onuncu ay, yirmi altıda uçup gitti. KT D 29(...) Tanrı bağışlasın, devletim var olduğu için, kısmetim var olduğu için, ölecek milleti diriltip besledim. Çıplak milleti elbiseli, fakir milleti zengin kıldım. Az milleti çok kıldım. Değerli illiden, değerli kağanlıdan daha iyi kıldım (...). KT D 11 Yukarıda Türk Tanrısı, Türk mukaddes yeri, suyu öyle tanzim etmiş, Türk milleti yok olmasın diye, millet olsun diye babam İlteriş Kağanı, annem İlbilge Hatunu göğ̈̈̈n tepesinde tutup yukarı kaldırmış olacak (...). KT D 21-23 Doğuda Kadırkan ormanını aşarak milleti öyle kondurduk, öyle düzene soktuk. Batıda Kengü Tarmana kadar Türk milletini öyle kondurduk, öyle düzene soktuk. O zamanda kul kullu olmuştu. Cariye cariyeli olmuştu. Küçük kardeş büyük kardeşini bilmezdi, oğlu babasını bilmezdi. Öyle kazanılmış, düzene sokulmuş ilimiz, töremiz vardı. Türk, Oğuz beyleri, milleti işitin: Üstte gök basmasa, altta yer delinmese, Türk milleti, ilini töreni kim bozabilecekti? Türk milleti, vazgeç, pişman ol! Disiplinsizliğinden dolayı, beslemiş olan bilgili kağanınla, hür ve müstakil iyi iline karşı kendin hata ettin, kötü hale soktun. Silahlı nereden gelip dağıtarak gönderdi? Mızraklı nereden gelerek sürüp gönderdi. Mukaddes Ötüken ormanının milleti, gittin (...). KT G 3,4 (...) Bunca milleti hep düzene soktum. O şimdi kötü değildir. Türk kağanı Ötüken ormanında otursa ilde sıkıntı yoktur. Doğuda Şantung ovasına kadar ordu sevk ettim, denize ulaşmama az kaldı. Güneyde Dokuz Ersine kadar ordu sev ettim, Tibete ulaşmama az kaldı. Batıda inci nehrini geçerek Demir Kapıya kadar ordu sevk ettim. Kuzeyde YirBayırku yerine kadar ordu sevk ettim. Bunca yere kadar yürüttüm. Ötüken ormanından daha iyisi hiç yokmuş. Il tutacak yer Ötüken ormanı imiş (...). KT G 10 Kağan oturup aç, fakir milleti hep toplattım. Fakir milleti zengin kıldım. Yoksa bu sözümde yalan var mı? Türk beyleri, milleti bunu işitin! Türk milletini toplayıp il tutacağını burada vurdum (...). KT D 13 Yedi yüz er olup ilsizleşmiş, kağansızlaşmış milleti, cariye olmuş, kul olmuş milleti, Türk töresini bırakmış milleti, ecdadımın töresince yaratmış, yetiştirmiş. Tölis, Tarduş milletini orda tanzim etmiş. KT D 16 Babam kağan öylece ili, töreyi kazanıp, uçup gitmiş. Babam kă̆an için ilkin Baz Kağanı balbal olarak dikmiş. O töre üzerine kağan oturdu. Amcam kă̆an oturarak Türk milletini tekrar tanzim etti, besledi. Fakiri zengin kıldı, azı çok kıldı. KT G 8 O yere gidersen, Türk milleti öleceksin! Ötüken yerinde oturup kervan, kafile gönderirsen hiçbir sıkıntın yoktur. Ötüken ormanında oturursan ebediyen il tutarak oturacaksın. KT D 19 (...) Ecdadımızın tutmuş olduğu yer, su sahipsiz olmasın diye az milletini tanzim ve tertip edip ... BK D 11,12 (...) Tanr kuvvet verdiği için, babam kă̆anın askeri kurt gibi imiş, düşmanı koyun gibi imiş. Doğuya batıya asker sevk edip toplamış, yığmış. Hepsi yedi yüz er olmuş. Yedi yüz er olup ilsizleşmiş, kă̆ansızlaşmış milleti, cariye olmuş, kul olmuş 
milleti, Türk töresini bırakmış milleti, ecdadımın töresince yaratmış, yetiştirmiş (...). BK G 9,10 Ben on dokuz yıl şad olarak oturdum. On dokuz yil kă̆an olarak oturdum, il tuttum. Otuz bir ... Türküm için, milletim için iyisini öylece kazanıverdim (...). T2 D 3-6 (...) Kă̆anımla ordu gönderdim. Tanrı korusun, bu Türk milleti arasında silahlı düşmanı koşturmadım, damgah atı koşturmadım. İltiriş Kağan kazanmasa ve ben kendim kazanmasam, il de millet de yok olacaktı. Kazandığ 1 için ve kendim kazandığım için il de il oldu, millet de millet oldu (...). T2 G 4-6 İltiriş Kağan bilici olduğu için, cesur olduğu için, Çine karşı on yedi defa savaştl, Kıtaya karşı yedi defa savaştı, Oğuza karşı beş defa savaştı. Onlarda müşaviri yine bizzat ben idim, kumandanı yine bizzat ben idim (...)" (Ergin, 2019: 87).

\section{Yardımseverlik Değeri}

Orhun Abidelerinde kağanların milletinden zorda olanların dertleriyle dertlendiğini, onlara yardım etmek, onların ihtiyaçlarını gidermek için çaba sarf ettiğini görmekteyiz. Abidelerde 'fakir olanları zengin kılmak, çıplak olanları giydirmek, ölecek olanları diriltip, beslemek' ifadelerinden halktan ihtiyaç sahibi olanlara yardım edildiğini ve onlara sahip çıkıldığını görmekteyiz. Abidelerde ifade edilen, devletini, milletini ve çevresinde yaşayan toplumları tanzim etme çabası da Türk toplumunda yardımseverlik değerinin önemini göstermektedir. Orhun Abidelerinde Yardımseverlik değeri ile ilgili şu ifadeler yer almaktadır:

“KT D 27-29 (...) Öyle kazanıp bütün milleti ateş, su kılmadım. Ben kendim kă̆an oturduğumda, her yere gitmiş olan millet öle yite, yaya olarak çılak olarak dönüp geldi. Milleti besleyeyim diye, kuzeyde Oğuz kavmine doğru, doğuda Kıtay, Tatabı kavmine doğru, güneyde Çine doğru on iki defa büyük ordu sevk ettim, ... savaştım. Ondan sonra, Tanrı bağ̆ışlasın devletim var olduğu için, ölecek milleti diriltip besledim. Çıplak milleti elbiseli, fakir milleti zengin kıldım. Az milleti çok kıldım. Değerli illiden, değgerli kă̆anlıdan daha iyi kıldım (...). KT D 16 (...) Amcam kağan oturarak Türk milletini tekrar tanzim etti, besledi. Fakiri zengin kıldı. Azı çok kıldı. KT G 10 Kağan oturup aç, fakir milleti hep toplattım. Fakir milleti zengin kıldım. Az milleti çok kıldım. Yoksa bu sözümde yalan var mı? (...). KT D 21 Doğuda Kadırkan ormanını aşarak milleti öyle kondurduk, öyle düzene soktuk. Batıda Kengü Tarmana kadar Türk milletini öyle kondurduk, öyle düzene soktuk (...). BK D 14 O töre üzerine amcam kağan oturdu. Oturarak Türk milletini tekrar tanzim etti., tekrar besledi. Fakiri zengin kıldı, azı çok kıldı (...). T2 K 4 Türk Bilge Kağanı Türk Sir milletini, Oğuz milletini besleyip oturuyor." (Ergin, 2019: 51).

\section{SONUÇ}

Türk milletinin ilk yazılı belgeleri olan Orhun Abideleri, Türklerin tarihte ortaya koyduğu en önemli bağımsızlık sembollerinden olmuş, Türk kültür ve medeniyetinin şaheseri olarak kabul edilmiştir. Orhun Abidelerinde Sosyal Bilgiler Dersi Öğretim Programında yer alan değer örneklerinin bulunması ve bu değerlerin Sosyal Bilgiler öğretimindeki önemi açısından değerlendirilmesi amacıyla yapılan çalışmada, Sosyal Bilgiler Dersi Öğretim Programında (MEB, 2018) adalet, aile birliğine önem verme, bağımsızlık, barış, bilimsellik, çalışkanlık, dayanışma, duyarlılık, dürüstlük, estetik, eşitlik, özgürlük, saygı, sevgi, sorumluluk, tasarruf, vatanseverlik, yardımseverlik olarak yer alan 18 değerin, Orhun Abidelerinde bulunduğu belirlenmiştir. 
Toplumu meydana getiren bireyler milli ve manevi değerlere bağlı olmalı, bu değerleri unutmamalıdır. Bireyler kendi toplumlarından kültürel anlamda uzaklaşmamalı, başka toplumların kültürlerinin etkisi altında kalmamalıdır. Kendi toplumunun kültürüne yabancılaşan, özünü yitirir. Bu özü yitiren özgürlügünü yitirir, diğer milletlerin esareti altına girer. $\mathrm{Bu}$ sebeple kendi kültürüne sahip çıkmak büyük önem arz eder. Bunu gerçekleştirebilmek ise aile ve okul aracılığıyla çocuklara kültürün aktarılmasıdır (Tezcan, 2015: 88).

Asırlarca ayakta kalmış, özgürlük, bağımsızlık, vatanseverlik gibi Türk milletinin tarihinde ve karakterinde çok önemli bir yere sahip olan kavramların, değerlerin unutulmaması, yaşatılması ve bu değerlerin gelecek nesillere aktarılması bakımından Orhun Abideleri büyük önem arz etmektedir. Asırları aşan mesajlar vermesi, Türk milletinin özünü tanıması ve medeniyetinden güç alarak geleceğe yürümesi bakımından bu abidelerin zihinlere kazınması çok önemlidir.

Sonuç olarak, Türk azmini, Türk kültürünü, medeniyetini ve Türklügün milli değerlerini yansıtmakta eşsiz bir eser olan Orhun Abidelerine öğretim programlarında yer vermek, öğrencilerin istifadesine sunmak, milli değerlerine bağlı, kültür ve medeniyetini tanıyan, topluma yararlı bireyler yetiştirmek adına büyük önem arz etmektedir. Bu bağlamda Sosyal Bilgiler dersi değer aktarımı etkinliklerinde Orhun Abidelerinden yararlanılması gerekmektedir.

\section{KAYNAKÇA}

Ata, A. (2012). Köktürkler. Gürer Gülsevin ve Mehmet Mahir Tulum (Ed.), Orhun Türkçesi içinde (s. 37-48). Eskişehir: Anadolu Üniversitesi Yayınları.

Atsız, N. (2014). Türk edebiyatı tarihi. İstanbul: Ötüken Yayınları.

Çelik, U. A. (2016). Orhun yazıtlarının sosyal bilgiler öğretim programında yer alan değerler çerçevesinde incelenmesi. Akademik Bakış Dergisi, 55, 47-61.

Demir, Ö. ve Acar, M. (1992). Sosyal bilimler sözlüğ̈̈. İstanbul: Ağaç Yayıncılık.

Ercilasun, A. B. (2015). Başlangıçtan yirminci yüzyıla Türk dili tarihi. İstanbul: Akçağ Yayınları.

Ergin, M. (2019). Orhun abideleri. İstanbul: Boğaziçi Yayınları.

Kardaş, M. N. (2015). Orhun abidelerinin Türkçe öğretiminde değer aktarımı açısından önemi II: Kül Tigin abidesi. Karadeniz Sosyal Bilimler Dergisi, 7(2).

Keskin, Y. (2012). Sosyal bilgiler öğretiminde değerlerin rolü. Değerler Eğitimi Uluslararası Konferansı 28-29 Mayıs 2010 (s. 68-102). İstanbul: Damla Yayınevi.

Konur, E. (2016). Orhun Yazıtlarında Sosyal ve Siyasi Mesajlar. https:/turkcetarih.com/uploads/wpbackup/orhun-yazitlarinda-sosyal-ve-siyasimesajlar.pdf Erişim Tarihi: 06.11.2019.

MEB. (2018). Milli eğitim bakanlı̆̆ı sosyal bilgiler dersi öğretim programı. Ankara: MEB Yayınları. 
Sallabaş, M. E. (2012). Ömer Seyfettin hikayelerinin Türkçe öğretiminde değer aktarımı bakımından incelenmesi. Mustafa Kemal Üniversitesi Sosyal Bilimler Enstitüsü Dergisi, 59-68.

Sever, M. (2010). Orhun yazıtlarındaki bazı kavramları yeniden okumak. Orhon Yazitlarının Bulunuşundan 120 Yıl Sonra Türklük Bilimi ve 21. Yüzyıl 3. Uluslararası Türkiyat Araştırmaları Sempozyumu. 727-733.

Şenocak, E. (2001). Göktürk yazıtlarında Türk halk edebiyatı unsurları. Fırat Üniversitesi Sosyal Bilimler Dergisi, 11(2), 165-176.

Tekin, T. (2018). Orhon yazıtları. Ankara: Bilgesu Yayınları.

Tekin, T. ve Ölmez, M. (2014). Türk dilleri. İstanbul: Bilgesu Yayınc1lık.

Tekşan, K. (2012). Türkçe dersi değerler eğitiminde Kutatgu Bilig' in kullanımı. Ahi Evran Üniversitesi Kırşehir Eğitim Fakültesi Dergisi, 13(3), 1-17.

Tezcan, M. (2015). Eğitim sosyolojisi. Ankara: Anı Yayıncılık.

Topsakal, C. (2018). Orhun yazıtlarının eğitim bilimleri açısından incelenmesi. Recep Tayyip Erdoğan Üniversitesi Sosyal Bilimler Dergisi, 8, 296-312.

Türkmen, F. (2013). Kök-Türk abidelerinde milli kimlik hassasiyeti. Milli Folklor, 25(9)7, 3138.

Yıldırım, A. ve Şimşek, H. (2017). Sosyal bilimlerde nitel araştırma yöntemleri. Ankara: Seçkin Yayıncilik. 